\title{
LA REVOLUTION OU LA MORT: RAYMOND LEFEBVRE AND THE FORMATION OF THE FRENCH COMMUNIST PARTY ${ }^{1}$
}

\author{
". . un vrai révolutionnaire n'est \\ qu'un pacifique à bout de patience." \\ Raymond Lefebvre, 1920.
}

The year was 1920, the month September. Three men, one young and impatient, the other two calmer, less flushed, prepared their things and packed them in the tiny sailboat that was to ferry them across the White Sea. The sailboat left the shore, disappeared slowly from sight and was lost in a flood of grey. The three men were never heard from again.

The young man's name was Raymond Lefebvre. He was hurrying home from Communist Russia, the land of Soviets, of Bolsheviks, and of rampant revolution, to which he had come to look, to listen, and to plead the cause of a select and pure Communist party in France before the Second World Congress of the Third International. At Moscow Lefebvre had impressed such tempered revolutionaries as Zinoviev, Trotsky and Victor Serge with his gift for language, his sincerity, and, above all, with his feverish, almost mystical faith in the necessity of world revolution. They saw in him one of the future leaders of the French Communist Party to the foundation of which the Executive of the Third International had recently devoted a good deal of its attention. Dedicated Communists like Lefebvre, they hoped, would counterbalance the Frossards and Cachins who had come to Moscow reluctantly to negotiate the incorporation in toto of the French Socialist Party into the Third International. One cannot help but think of John Reed: Like Reed, Lefebvre was a talented writer, though more a poet than a journalist. Like him also he had been an early convert to Bolshevism. And, just as in the case of the American Communist, Lefebvre died an early death in circumstances which have never been fully clatified and which later gave rise to allegations of foul play.

1 The research for this article was made possible by a grant from the Ford Foundation. 
Traveling with him were Vergeat and Lepetit, the one an anarchist, the other a revolutionary syndicalist, who had come to see the reality of the Russian Revolution with their own eyes.

Today it is hard to reconstruct the enthusiasm with which the left wing of the French revolutionary movement looked to the East in 1919 and 1920: those were years of reaction and disillusionment at home and corresponding faith in the panacea of the Russian Revolution. ${ }^{1}$ The revolutionaries of France saw in the Russia of Soviets a utopia where the domination of man by man had at last been ended and in Lenin and Trotsky two prophets of superhuman stature who would lead the West out of its torpor. For the first time in decades, it seemed that the traditional divisions in France between anarchists, revolutionary syndicalists and Socialists would be superseded in the new enthusiasm for Bolshevism. The anarchists and revolutionary syndicalists had made contact with Bolshevism through Lenin's State and Revolution; they had come away from their reading seduced and charmed. Finally, they murmurred, they had found a Socialist who recognized that the state was superfluous and who did not shiver before the thought of violence. ${ }^{2}$ Moreover, the revolutionary syndicalists saw in the mass movements of the Russian Revolution the ultimate vindication of their doctrine of mass and action, and noted with approval that the workers had been given control of the factories. In 1919 and 1920 , these two years of confusion and hope, anarchists, revolutionary syndicalists and leftwing journalists in search of a headline proudly proclaimed themselves Bolshevists without stopping to ask themselves what Bolshevism was: the word was in style. ${ }^{3}$

The Socialists were more cautious, particularly the leaders; but they too were fascinated - or, as in the case of the more conservative, embarrassed - by the fact that the Revolution had succeeded and that at Moscow there was a state which actually intended to apply the teachings of Karl Marx. As thousands upon thousands of new recruits poured into the Party and the unions flooding the old cadres,

' Gaston Monmousseau later wrote of that epoch: "If someone had said to us at that moment, "You are blindly following Lenin", they would have been saying only the strict truth. But if they had added, "You are merely adoring the Leninist deity", we would have responded in all simplicity, "We do not know exactly what Leninism is, but we love and follow Lenin because he is the leader of the Socialist Revolution and we are revolutionaries." Quoted in Val Lorwin, The French Labor Movement (Cambridge I954), p. 5 I-52.

2 Alfred Rosmer, Moscou sous Lénine (Paris 1953), p. 7 I-73.

3 In France the revolutionary syndicalists and the anarchists immediately felt closer to the Bolsheviks and with some reason. Trotsky was a close personal friend of Monatte and Rosmer and had preferred the company of the revolutionary syndicalists and the anarchists while he was in France to the Socialists whom he almost universally despised and distrusted. Ibid., p. I03-104. See also Leon Trotsky, My Life (New York 1930), p. 247. 
the leaders lost control of their troops. A gap appeared between generations. The generation of men who had suffered the agony of trench warfare felt permanently alienated from the Socialist and syndicalist leaders who had remained at home preaching victory at any cost and advocating war to the bitter end. ${ }^{1}$

This essay tells the story of Raymond Lefebvre. But it is more than the story of a man: it is the story of a generation. Like so many other French revolutionaries after him, Lefebvre went to Russia to search for what he found lacking in France. He belonged to the generation that had come to maturity just before the War. He had passed his adolescence in the shadow of the German menace. As Daniel Halévy pointed out, many of the young men of Lefebvre's generation had spent six or seven years under arms by 1919; the formative years of their life had been spent on the battle fields of World War I. Some, like Lefebvre, had marched almost directly from the lecture hall to the trenches without breaking step. "For them all", wrote Halévy perceptively, "decimation, and, at twenty-five, a tragic feeling of survival. Rare, and all the more precious, what will they do?" 2

Many of these young men emerged from the War determined that something very basic in European civilization had to be changed. They were in search of a mystique; many of them had lost their faith in Western democracy. After a brief flirtation with Wilsonianism that ended in bitter disillusionment, Lefebvre found his answer in Bolshevism and Soviet democracy. He believed that Communism offered the only hope for a West that had fought and bled itself to the very precipice of decadence. This is his story.

\section{III}

Raymond Lefebvre was born at Vire in $189 \mathrm{I}$ of well-to-do Protestant parents. He spent a sickly childhood in his native Normandy where he attended school until transferring to the Lycée Janson de Sailly in Paris. His grandfather had been a militant royalist and, some wags suggested, an intimate of the Count de Chambord; his parents were

1 This question of generations and the psychological schism within the working class organizations is not one that can be definitively settled here. I hope to discuss it at greater length in my forthcoming book on the origins and development of the French Communist Party, 1914-1924. For the moment I will limit myself to citing two observers who noted this phenomenom and who were in a position to know. Jean Longuet, Humanité, February II, I920; and L.-O. Frossard, De Jaurès à Lénine (Paris 1933), p. 71. This essay, of course, presents a case study of one young Socialist in whom this alienation was dramatically evident.

2 Pierre Drieu la Rochelle, Mesure de la France (Paris 1922), p. v-vi. 
solid members of the bien pensant community. Lefebvre himself has left a colorful description of the conservative milieu in which he grew up. With any other writer one would laugh, but Lefebvre was deadly serious; he feared and despised the powers of survival of the French bourgeoisie:

"There was a lot of talk of the Dreyfus affair, but without emotion. The unanimity of opinion left no doubt that Dreyfus was a traitor, Zola a scoundrel, Henry a touching victim. I did not doubt it either... One didn't let the young girls read the new novels of Bourget before having read them first to scratch out the improper passages ... Of Anatole France only the Crime de Sylvestre Bonnard was permitted ... Socialist, anarchist, assassin were synonyms; only my mother knew that they were three different things, for she told me once and I remained surprised." 1

At the Lycée Janson in Paris Lefebvre made the friendships which he would maintain for the rest of his life. There he met Paul VaillantCouturier, Jean d'Eserpouy and Guy de la Batut. Together they read and discussed contemporary literature, revealed to one another their first groping efforts at poetry and art, and searched for a view of life which would satisfy both their heart and their head. As VaillantCouturier later recalled, "They were in search of an order, of a discipline of combat." 2 Lefebvre, partly for reasons of family, partly because of his love of history, was temporarily seduced by Maurras and the Action Française. ${ }^{3}$ In the literature of the day he read and admired Barrès for his unabashed nationalism. It is interesting to note that these four young intellectuals in search of an ideology dismissed Socialism because it did not appeal to their sense of mysticism and action. Although they admired the idealism of Jaurès and the biting consistency of Guesde, they were disgusted by the band of Socialist politicians who followed in their coattails; and they saw little to choose between the Socialists and the Radicals who shared an insipid anticlericalism and a boundless greed for elective office. ${ }^{4}$ They were much more attracted by the revolutionary syndicalists and Marc Saignier's Christian Socialists who satisfied their need for idealism and social action. But in the case of the revolutionary syndicalists they were restrained by the presence of dangerous anarchists and agents provocateurs, and perhaps also by a trace of snobbism; and with the Christian Socialists they were disturbed by the disapproval of the

1 Raymond Lefebvre, L'Eponge du Vinaigre (Paris I92I), p. Ig.

2 Paul Vaillant-Couturier, Enfance (Paris 1938), p. 249.

3 Ibid., p. 249.

4 Ibid., p. 2 so. 
Vatican. Thus, they ended by taking refuge in a kind of intellectual anarchism and utter disdain for the regime.

Lefebvre spent the three years directly preceding the War at the Sorbonne and the Ecole des Sciences Politiques where he passed both his degree in law and in history. There he became close friends with Drieu la Rochelle who has left a description of him at that time. Strong, intense, dominating, he was known among his fellow students as something of a dandy and an anglophile. "He was strong," wrote Drieu. "There was an authentic force in this boy: uneven forehead, sharp nose, deadly glances, thin lips, pointed teeth, steely jaw." 1 Unlike the other members of his circle, Lefebvre was intensely religious. Although he remained a Protestant in name, he had evolved toward the mystical Catholicism of the Oxford movement. Drieu la Rochelle felt nonplused before the assurance of Lefebvre's faith in God. Already Drieu had sensed in the personality of this large and awkward boy a quest for an ideology that would explain the world, yet give a means of acting upon it, of changing it. "Everything in him was action", he wrote. "The books he read, his conversation, even his leisure, were governed by the urgency to form a unity of character, of doctrine." 2

In 1912 Lefebvre had still felt the spiritual attraction of his conservative background. Drieu la Rochelle recalls that at that time they shared a feeling of fervent nationalism. ${ }^{3}$ Moreover, considering their age this was not at all unusual; everything suggests that they were moved by the ideas and emotions which Agathon described in 1912 in Les Jeunes Gens d'Aujourd'bui. Toward I9I3, however, Lefebvre began to evolve to the Left. Later, at the Congress of Strasbourg, he described before his fellow Socialists how painful this process had been. It meant breaking with his family and all the values of nation and class which he had been taught to hold dear. ${ }^{4}$ He became a subscriber to Pierre Monatte's Vie Owvrière which represented the militant revolutionary syndicalist point of view. He began to read and approve the articles of Jaurès, and he transformed his mysticism into internationalism and a faith in the proletariat. ${ }^{5}$ In 1913 both he and Vaillant-Couturier went down into the street in the Latin Quarter in order to demonstrate against the three year law. Since I9I 2 he had participated in the working class manifestations of the first of May. He

1 Pierre Drieu la Rochelle, Mesure de la France (Paris 1922), p. 159.

2 Ibid., p. I 49.

3 Ibid., p. Is3.

4 Parti Socialiste, S.F.I.O., 1 7e Congrès National, tenu à Strasbourg les 25, 26, 27, 28 et 29 Février 1920, Paris I920), p. $250-25 \mathrm{I}$.

5 Paul Vaillant-Couturier, Enfance, p. 25. 
still however refrained from joining the Socialist Party, perhaps because he continued to feel that it was dominated by opportunists and politicians. He undoubtedly was much more attrected by revolutionary syndicalism. But the revolutionary syndicalists spurned the help of intellectuals and prided themselves on their proletarian character and lack of theory. Then came the War and the failure of European Socialism. Within a month Guesde and Sembat had accepted portfolios from the government, Jouhaux had offered his services as commissar to the nation, and in Switzerland Lenin was proclaiming to all who would listen that the Second International was dead: Long live the Third! 1

\section{IV}

The War was without any doubt the central experience of Lefebvre's brief life. He went to war a boy, talented but still undecided and uncommitted regarding his future and his values; he came back a man, bitter, steeled, determined, and dedicated to the cause of Revolution in France. For Lefebvre the beginning of the War had marked the death rattle of European civilization. An entire world had marched gaily to its destruction singing patriotic songs and chanting "On to Berlin", yet few people, later recalled Lefebvre, had realized the importance of that fatal day. Looking back, he could scarcely believe his memories: people had posed, had fixed their faces with a grave smile and then had gone to have themselves photographed before the eternal gaze of History. "No", he wrote. "No one suddenly heard that slamming of a door which closed itself behind us forever." 2

From the very beginning Lefebvre held fast to his internationalism and rejected the War as a catastrophe. But in those first days of chauvinist madness internationalists were few and far between. The militant resolutions of the Socialist Party and the Confédération Générale de Travail crumbled before the onslaught of the German armies. The turnabout was complete and accomplished with breathtaking speed. As Merrheim remarked to Lenin at Zimmerwald in I9I5, the Party, Jouhaux and the government had become "three heads under the same bonnet". ${ }^{3}$ In the fall of I9I4, after the first wave of enthusiasm had passed, Lefebvre was one of a small group of inter-

\footnotetext{
1 The best and most complete study of the reaction of the French Socialists and syndicalists to the coming of the War is still Alfred Rosmer, Le Mouvement ouvrier pendant la guerre (Paris I936), Vol. I.

2 Raymond Lefebvre, Le Sacrifice d'Abraham (Paris I9I9), p. I.

3 Quoted in N. Lenine and Georges Zinoviev, Contre le courant (Paris I 927, 2 Vol.), Vol. II, p. I9.
} 
nationalists which met at the offices of the Vie Owriere and kept alight the flame of opposition to the War. There he met Alphonse Merrheim, Bourderon, Pierre Monatte, Alfred Rosmer, Henri Guilbeaux and Trotsky, who had just reached France from Austria. Lefebvre has left an eloquent memoir of those grim meetings on the Quai de Jemappes:

"We contented ourselves to poke sadly the cold remains of the International: to draw up, with bitter memory, the immense list of those who had failed, to forsee with useless clairvoyance the length of a struggle of attrition in which civilization alone would be vanquished." 1

By the winter of 1914 Lefebvre himseld had been called. He first served as a stretcher bearer and nurse. At this post he saw the War at its worst and most horrible. Soon after going to the front he wrote to Vaillant-Couturier, describing to him the inferno in which he lived and urging him to hold fast:

"We live in an ignoble butchershop in which the meat is spoiled

by necrosis and tetanus, he cried. The atmosphere is acrid and the ammoniac gas which rises from gangrened wounds, full of maggots, brings tears to the eyes. Don't rot in this charnel house. And also, at least, don't fall dupe to the patriots, under the shells." 2

During these first months of War, Lefebvre submitted all his values to a thoroughgoing reassesment. The world seemed to be tumbling down all around him; he lived in the continual sight and smell of death and destruction; the days and nights merged into a single, tortured nightmare without end or beginning. Later he wrote that "The world appeared to me then like an immense tale by Edgar Poe, and, more than one evening, I feared the haggard approach of madness." 3 The War completed the process which Lefebvre had begun in I9I3. In the mud of the trenches he broke finally with the values of his family, his nation and his class. He became convinced that the only hope of Europe lay in the reaffirmation of that internationalism which had died with the Second International.

The first months of the War had been the most difficult. Lefebvre and his friends had suffered terribly from their isolation. In the spring of Igrs, however, it became clear that they were not alone. Romain Rolland had already raised his voice in protest to the War by proclaiming that he would stand above the battle. At Paris Pierre Monatte signified his opposition to the chauvinistic policies of the leadership

1 Raymond Lefebvre, L'Eponge du Vinaigre (Paris 1921 ), p. 5-6.

2 Clarté, December $4,1920$.

3 Ibid., p. 6. 
of the C.G.T. by resigning from the Confederal Committee. In May the malaise within the Socialist Party burst out into the open. The Federation of the Haute-Vienne circulated a manifesto in which it protested in measured, but nevertheless, firm terms against the refusal of the Party's leaders to consider feelers extended by the Swiss and Italians for an international Socialist conference. ${ }^{1}$ And, far away in America, Wilson seemed to symbolize the forces of peace; at least, thought Lefebvre, one statesman had escaped the madness in which Europe had mortgaged its civilization and its future. ${ }^{2}$ The struggle against the War had begun.

Lefebvre saw action in the battle of Verdun and in 1916 was seriously wounded. After his recovery, which was never more than partial, he was appointed a legal counsel in the Conseils de Guerre, and for some months he defended soldiers who had been brought before court-martial for reasons of desertion, insubordination or cowardice under fire. At Verdun and in his work as legal counsel he converted more than one unbeliever; if anything, his faith in God had been reinforced during the War. In I916 he came back to Paris to await his discharge. He immediately joined the Socialist Party. According to Vaillant-Couturier, "It was the shame of the abdication of a Socialist party which incited him to join. It was necessary to return it to its original task, to make it take in hand the work of a revolutionary peace." ${ }^{3}$ He came back from the War aged beyond his years and suffering from a diseased lung. Vaillant-Couturier must certainly have been thinking of his friend when he wrote that "The children of twenty have aged ten years in three winters ..."4

Once back from the War, Lefebvre threw himself into the realization of the many projects which he had conceived during long, solitary hours in the trenches. Together with Georges Bruyère and VaillantCouturier, he founded the Association Républicaine des Anciens Combattants (A.R.A.C.), and became its secretary. At the same time, he went to see Anatole France, Henri Barbusse and other intellectuals and proposed to them the idea of an international literary review which would break with the current criteria of criticism, appear in several languages and express the union of European intellectuals. This was the origin of the review Clarté. Lefebvre had come home

1 For Romain Rolland see his Au-dessus de la Mêlée (Paris I9I 5). For Pierre Monatte and the C.G.T. and for the Socialists see Alfred Rosmer, Le Mouvement ouvrier pendant la guerre, Vol. II, where the relevant documents are reproduced.

2 Raymond Lefebvre, L'Eponge du Vinaigre, p. 8.

3 Humanité, November I, I92I.

4 Paul Vaillant-Couturier, Lettres à mes amis (1918-1919), (Paris 1920), p. 45. The preface is by Lefebvre and is particularly revealing for the development of his ideas. 
obsessed with the need for brotherhood and internationalism. His first action in the Socialist Party was to submit a motion to his section (the I6th) calling for the organization by the Federation of the Seine of a great manifestation in honor of Karl Liebknecht. The theme of the demonstration was to be the committment by the Socialists to refuse all service in the munitions factories and in the trenches the minute that the German Republic was proclaimed. ${ }^{1}$ The manifestation, of course, was never held.

Lefebvre was tortured by the menace of European decadence; for him the War had ended one epoch and begun another. Although no one may have been listening, a door had slammed shut on Europe that day of August 2, I9I4, when France had gone so lightheartedly to War. "How many slow centuries", asks the main character in one of Lefebvre's books, "will have to run out their empty hours upon the world before, patiently, awkwardly, man reconquers the civilization that he has let escape from him?" 2

Thus the War had dealt a mortal blow to European civilization. But, by civilization, Lefebvre meant bourgeois civilization. There was still an opportunity for the proletariat to salvage the remains of what the bourgeoisie had squandered and destroyed in the War and to rebuild a new and healthy society upon the ruins. In this sense, thought Lefebvre, the War had exercised a beneficial effect for it had acted as a unifying experience for the nation and particularly for the proletariat, the peasantry, and the intellectuals. All those who had suffered the agonies of the War would forever be bound together spiritually by the memory of that terrible experience; this was the basis for the Association Républicaine des Anciens Combattants and this was why Lefebvre devoted so great a part of his energies to it: "For the great suffering elevates and fortifies, enlightens those that it cannot crush. This is why to have served in this war will be a title: people will know that for several years some species of hermits, muddy and covered with blood, will have bitterly stigmatized the vices of a Society which made such insolent use of their flesh and their dignity, which squandered so madly this thing so slow to grow and delicate that one calls a man, and who will have understood at once the infamy of a certain number of concepts which up to then had been considered venerable, and the justice of a certain number of ideas which up to then had been held to be utopian."2

Thus, the War had brought together intellectuals, peasants and workers and had united them in their suffering. It was Lefebvre's

1 Clarté, December Is, 1923.

2 Raymond Lefebvre, Le Sacrifice d'Abraham, p. 265-66. 
belief that they could be maintained united after the War and that they would furnish a great revolutionary army which would overthrow the present bourgeois regime and safeguard the peace. The veterans of the Great War must remain banded together in order to engrave upon the memory of the oncoming generations the record of what the War had been. There must be along with the congresses of the Socialist and syndicalist internationals, wrote Lefebvre, a congress of victims "which will be the definitive treason of Humanity to the Duty of Hate." 1 The intellectuals of Europe must create and foster a horror literature so that the War would never be forgotten. In I9I7 Lefebvre and Vaillant-Couturier collaborated to make the first installment on that literature, La Guerre des Soldats, a collection of descriptive episodes based on their respective war experiences, but presented in fictional form. It bore the dedication "to those who have fought without hate, to those who hated without fighting." 2 As VaillantCouturier wrote, "We will ceaselessly throw it (the War) in your face, for we will have kept intact in our memory the odors that the salts of the earth will have neutralized in such a way that you will be pursued by them throughout the world like by a great wind from the charnel house." 3

Lefebvre often went so far as to speak of the War in quasi-religious terms: The War left a mark on men which, like the imprint on the shoulder of the convict, reappeared at the slightest pressure. More than one man, wrote Lefebvre, had experienced a moment of revelation on the field of battle and had vowed to give his life, if he returned, to the task of building a new Europe free from capitalism and imperialism. ${ }^{4}$

Lefebvre had returned from the War determined and angry, but he lacked a definite program. He was driven by a burning but vague faith in the powers of the proletariat to regenerate France. He believed the experience of the War would kindle the anger of the downtrodden classes and act as the cement which would make them a coherent force. Lefebvre chose the Socialist Party because it represented the proletariat and had behind it a tradition of internationalism. Like so many other French Socialists Lefebvre had no grounding in the

1 Raymond Lefebvre, L'Ancien soldat (Paris n.d., 1919?), p. 4.

2 Ibid., p. Is.

3 Paul Vaillant-Couturier and Raymond Lefebvre, La Guerre des Soldats (Paris 1919).

4 Paul Vaillant-Couturier, Lettres à mes amis (19r8-19t9), p. 45.

5 Raymond Lefebvre, L'Ancien soldat, p. 5. 
principles of Marxism and cared less. ${ }^{1}$ If he had any doctrine it was a tragic sense of European decadence and a cult of action which he shared with his generation, but which was contrary to the optimistic and democratic traditions of the Socialist Party. Lefebvre found his ideology in the Bolshevik Revolution and it is this that makes his case particularly interesting. He was a post-I 9I4 Socialist just as Gaston Monmousseau, for example, was a post-I9I4 syndicalist. ${ }^{2}$ Driven into the Party by a hate for war and the people who cause it, taking his weapons almost at random in the ideological grabbag of Bolshevism, Lefebvre typified the generation which founded the Communist Party in France.

When Lefebvre came back to Paris from the front he found the Socialist Party torn between two warring groups: the majoritaires and the minoritaires, as they were christened according to their strength in the Party. The majority, inspired and directed by Albert Thomas and Pierre Renaudel, had thrown the Party heart and soul into the war effort. Albert Thomas himself served as Minister of Armament. The majority believed that the German Socialists had betrayed their committments by supporting a war of aggression. They felt a negotiated peace was impossible. German militarism must be once and for all wiped off the face of the earth; Alsace-Lorraine must be reunited with France. The minority, on the other hand, led by Jean Longuet, the grandson of Karl Marx, wanted first to restore the unity and moral authority of the International by meeting with the other parties, including the belligerents, and then to seek a negotiated peace which would recognize the justice of French claims. The minoritaires, however, did not contest the right to national defense; when the chips were down they swallowed their criticisms and voted with the majority. ${ }^{3}$ On the outskirts of the minority was a

1 An anecdote recounted by Henri Guilbeaux makes this point well. In 19I7, while in Switzerland, Lefebvre complained to Guilbeaux about Loriot. Loriot, insisted Lefebvre, weakened the minority by constantly presenting his own motions. "Mais c'est un marxiste", replied Guilbeaux. "Un marxiste!" groaned Lefebvre. "Ah, nous y voilà! mais c'est bien pour cela qu'il est sinistre." "Avez-vous lu Marx?" asked Guilbeaux. "Non, et je ne le lirai jamais. Marx est un emmerdeur." Henri Guilbeaux, Du Kremlin au ChercheMidi (Paris 1933, 5 th ed.), P. I4I-I 42.

2 I owe this point to Madame A. Kriegel who is preparing a thesis on the French working class movement during the years $1914-1920$ and who has done much to deepen my understanding of this period.

3 Which is why Trotsky considered them more dangerous than the majority. Wrote Trotsky in late 1916: "Si Renaudel et Sembat ont compromis le parti, l'organisation, la tradition officielle, Longuet et Pressemane sont en train de compromettre l'idée meme de la rébellion réparatrice contre cette trahison historique sans précédent." Vie Ouvrière, Vingt Lettres de Léon Trotsky (Paris 1919), p. 26. For the position of the majority see Le Parti socialiste: la guerre et la paix (Paris 19 I 8) and Humanité. For the minority the best sources are the Populaire du Centre and the Populaire Socialiste-Internationaliste which was launched in 1916. 
tiny group of Zimmerwaldians, represented by Fernand Loriot, Charles Rappoport and Louise Saumoneau, which urged the minority to take more resolute action and, chiefly, to vote against the war credits. Loriot had collaborated closely with Trotsky in the Committee for the Resumption of International Relations and had even gone to Switzerland in order to meet Lenin in the spring of 1917; but he was anything but a Leninist. He knew that it was impossible to advocate civil war in France with Germans occupying French soil. ${ }^{1}$ The majority had managed to preserve the leadership of the Party at the National Congress of 1916 despite a vigorous attack from the minority. But it was clear that the minority was rapidly gaining ground within the Party and that it was only a matter of time before it would become the majority and take over the reins of the Party.

Lefebvre immediately lent his energies to the minority. He wrote for the weekly minoritaire review, Le Populaire Socialiste-Internationaliste, for Henri Fabre's left wing Journal du Peuple, and for La Verité; he propagandized for the minority in the sections; he tried to line up support for his international literary review; he worked feverishly to build up A.R.A.C.; and, in his spare moments, he collaborated with Vaillant-Couturier on La Guerre des Soldats and he began his first novel. Within the Party he was close to Longuet. Guilbeaux in his memoirs tells how hostile Lefebvre was to Loriot and the Zimmerwaldians in 1917 :

I pronounced Loriot's name, wrote Guilbeaux. Ah! Him, said Lefebvre, he is sinister! At every Congress he reads a resolution in a dismal tone of voice and he refuses to associate himself with our efforts. It is his fault that the Thomases, the Renaudels and the Cachins remain the masters of the Party. ${ }^{2}$

I917 was a year of despair for the Allies who suffered a serious defeat on the Western front and who saw the will to fight weaken within their peoples. It was a particularly grim year for the French government. ${ }^{3}$ But for the Socialists it was a year of hope. In February came the Russian Revolution and in May the majority of the French Socialist Party, turning about full circle, voted to accept the invitation of the Petrograd Soviet and Dutch-Scandinavian Committee to come to Stockholm for an international Socialist conference. In the summer

1 Parti Socialiste, S.F.I.O., I 7 e Congrès National, tenu à Strasbourg les 25, 26, 27, 28 et 29 Fevriet 1920, p. 439.

${ }^{2}$ Henri Guilbeaux, Du Kremlin au Cherche-Midi, p. I 41-I42.

3 See Raymond Poincaré, Au Service de la France (Paris 1926-33, ro Vols.), v. IX. See also the records of the German Foreign Ministry, 4301/D I 965054 , for an interesting report on the situation in France and its repercussions on the French Socialist Party. 
of 1917 Lefebvre wrote excitedly to Vaillant-Couturier: "The Russian Revolution fills me with joy and with anxiety." Would the soldiers of Petrograd know how to elect a Republican assembly, exile the Romanoffs, repudiate the panslavism of the bourgeois Liberals and keep high their red flag, asked Lefebvre anxiously? 1 "The life of Europe, of the entire civilized world, depends on the Russians", he wrote. But despite his enthusiasm Lefebvre saw nothing more in the Russian Revolution than the normal progression of the most backward state in Europe toward Western bourgeois democracy. And in the same letter he wrote: "Don't you think that a German defeat might provoke a Revolution? Revolution ... this is the 'word' of the entire world." 2 The Frenchman in Lefebvre, despite his advanced opinions, could not help but wish that the Germans would demand for themselves a Republic which he often unthinkingly identified with Revolution.

Lefebvre continued throughout 1917 and 1918 to share the ambiguous point of view of the minoritaires. He wanted to see the peace negotiated, but until the Germans had been driven from French soil he stood one hundred percent for national defense. In the spring of 1918 he said: "If Amiens falls into the hands of the Germans, I will leave again for the front as nurse-stretcherbearer." 3 He never joined the small Zimmerwaldian Committee for the Resumption of International Relations. He watched the progress of the Russian Revolution anxiously and he defended the Bolsheviks from time to time in the press, explaining why the Russians had been forced to sign a separate peace. But he still had very little understanding of what Bolshevism was or for that matter little interest in it. In January of I9I 8 he identified Wilson, Trotsky and the League of Nations as the camp of peace, Hindenburg, the imperialist powers and the Holy Alliance as the forces of war. ${ }^{4}$ Lefebvre was still not certain whether he was a Bolshevik, a Socialist or merely a good Republican. In April of 19 I 8 he announced the creation of a Republican Coalition. As soon as the German menace was banished, wrote Lefebvre, all good Republicans would band together to ensure that the reactionary French government respected and adhered to the Wilsonian policy of an honorable peace. ${ }^{5}$

1 Clarté, December 4, 1920.

2 Ibid.

3 Wilfred Monod, Documents sans commentaires (Paris 1922), p. 6.

4 La Verité, January 22, 1918.

5 Later Lefebvre called these two years the passive period and the beginning of the active period of his generation. Paul Vaillant-Couturier, Lettres à mes amis (1918-1919), p. 7-8. 
But as the War ended the situation changed. It became clear that the intervention in Russia was not directed toward reestablishing a second front in the East but was meant to suppress the Bolshevik Revolution. Like all French Socialists, Lefebvre felt keenly the failure of Wilson at the Peace Conference. He identified the failure of Wilson with the bankruptcy of Western democracy. He observed the increasingly reactionary policy of the government within the country. The spring of 1919 was a time of unrest throughout Europe and many thought that France also might follow the example of Russia, Hungary, Bavaria and Germany. ${ }^{1}$ In March of 1919 the Communist International, or Third International as it was commonly called, had held its first international congress. It had issued an appeal to the revolutionary forces everywhere in Europe to gather behind its banner and overthrow the bourgeoisie, replacing it with the dictatorship of the proletariat, as the Russians themselves had done. In April of that year the question of the Third International had first been put before the National Congress of the French Socialist Party. A large majority had voted to stay in the Second International for the time being, but it was clear that circumstances favored the Third International and that more and more the rank and file felt drawn by the enormous prestige of the Russian Revolution. The Second International had been discredited by its scandalous philanderings during the War with capitalist governments. Many felt that there was no need to destroy it; it had committed suicide in August, 1914. The Third International, on the other hand, was led by Lenin and Trotsky and was draped in all the revolutionary purity of the Soviet regime. Lefebvre had long been disgusted by the politicians of the Second International. He began to draw close to the small Committee of the Third International which had been formed in May of 19 I 9 and which was led by Loriot, Monatte and the talented young journalist, Boris Souvarine. He started to campaign for the Third International within the Party. And in September of that year he wrote a pamphlet for the Vie Ouvrière entitled "L'Internationale des Soviets" which is interesting because it revealed a basic step forward in his thinking.

Let no one say, wrote Lefebvre, that the difference between the two Internationals was a mere question of numerals or even of personalities and not of principles. "Men, tactics, doctrine ... there

1 Including Lloyd George who warned in March, 1919, in the memorandum which he presented to the Peace Conference: "The whole of Europe is filled with the spirit of revolution." Francesco Nitti, Peaceless Europe (London 1922), p. 94. 
is nothing more in common between them." 1 The Second was parliamentary, democratic, national. "The other, conceived in the terror of I9Is, in the noise of autumn offensives, is the daughter of war. It has this ardent and sad vehemence of those who have known the field of battle, and who have learned the European languages while listening to the cries of soldiers." 2 This new International was animated by a hate for the parlementarians who had betrayed it. It despised the democratic regime which permitted war profiteers to cover their operations with the mantle of legality. And, above all, it hated war, the army and the nation. "Finally", said Lefebvre, "it knows what one calls a Revolution and otherwise than by the brochures of Guesde or the in-quartos of Kautsky." 3 It elaborated its doctrine in the act. It wrote its program in the midst of the acclamations and anger of a Soviet without bothering to ask itself whether it was maximum or minimum. "Its leaders are the workers, the soldiers and the peasants of Europe. It is the coalition of recovered victims, it is the revolutionary dictatorship. It exists." 4

Lefebvre's pamphlet was penetrated with a scorn for parliamentary democracy. "A democracy", he wrote, "is the uncertain reign of the popular will surprised every four years in its sleep..." 5 The Soviet, on the other hand, insisted Lefebvre, using his imagination liberally, was more democratic. The delegate to the Soviet left his town for days, not for years. "... hence an honesty, a conscientiousness in the small things, a promptitude, and also a fidelity to the popular will that the present Democracies have rarely known even at their height. And then, above all, a youngness of heart ..." 6 The people, wrote Lefebvre, were tired of doing obeisance to their deputy, who, almost without exception, had betrayed them at the beginning of the War and would do so again given the opportunity. For Lefebvre the choice between the two Internationals was simple:

"Soviet or Parliament?

Democracy or Communism . . .?

Elections or Revolution?

Alliance with the bourgeois Left or with anarchistic syndicalism?"?

\footnotetext{
1 Raymond Lefebvre, L'Internationale des Soviets (Paris 1919), p. 5.

2 Ibid., p. 6.

3 Ibid., p. 6.

4 Ibid., p. 6.

5 Ibid., P. II.

6 Ibid., p. I 2.

7 Ibid., p. I4.
} 
In 1919 and 1920 Lefebvre threw himself into the struggle for the Third International with all his strength. In 1918 he had suffered a relapse from his weak lung and had had to consign himself to a sanitorium. He came back more wan, more feverish than ever, but determined to exhaust what energies he had in the struggle to purge the Socialist Party and take it to Moscow. Drieu la Rochelle, who had seen him only fleetingly since before the War, was struck by how he had changed. He was appalled by the ravages which Lefebvre bore upon his face and body and by the singlemindedness with which he had devoted himself to this new cause. "I could not believe", wrote Drieu, "that these sacrifices were all required by the ferocious god of Action." I In the elections of November I1, 1919, despite his revulsion for parliamentarism, Lefebvre presented himself as a candidate of the Socialist Party in the third sector of Paris. ${ }^{2}$ He was in search of a tribune from which he could reach the masses. The elections proved disastrous for the Socialist Party. Lefebvre himself missed victory only by the margin of a few undisciplined Socialist votes.

Lefebvre continued to be haunted by the spectre of European decadence. As Victor Serge later noted, this was more than an idea for Lefebvre; it was the very atmosphere in which his ideas lived. ${ }^{3}$ In I9 9 he published his first novel, Le Sacrifice d'Abrabam. Rough and obviously composed hastily, yet brilliant and powerful in snatches, it was the story of a stodgy academician, named Testut who is forced by the advance of the Germans to leave his home, his books and his manuscripts. Driven to Paris, Testut is enticed into becoming a patriotic publicist and gains an instant success with his anti-German tracts. When he has an opportunity to have his son transferred from the front to a position of safety behind the lines in Italy he refuses, carried away for a moment by his own propaganda and a feeling of patriotic rapture. Soon after, Testut discovers that his son has been killed. Overcome by remorse, he blames himself and rejects his role as a bourreur de crane. Toward the end of the novel Testut predicts gloomily:

"I see coming the reign of tyranny and of anarchy, of dictatorship tempered by riot ... Opulent, decadent wealth will live on misery. We will be cynical . . . and superstitious. Boxers and

\footnotetext{
1 Pierre Drieu la Rochelle, Mesure de la France, p. I60.

2 His name was proposed by Boris Souvarine.

3 Bulletin Communiste, October I 2, 1921 .
} 
fortune-tellers will reign. We will lead the lazy life of Spain. Ah yes! old boy! you look at me with stupor ... What I say, however, is normal and tenable . . . Where do you see a strong man? Where do you see a healthy social element?" 1

Lefebvre found the answer to European decadence in the new Soviet regime and the idea of world revolution. The bourgeoisie had had its turn before the bar of history; the War had consecrated its failure. Lefebvre believed firmly that the generation of men who had known at firsthand the field of battle would make the revolution out of a burning hate for those who had so lightly subjected them to this inferno. He himself was sometimes frightened by the hate which he detected in his own writings. "In truth", he explained, "this hate is not in my heart. It is in the very spirit of the century, it inflicts itself on man." 2

Lefebvre devoted the last year of his life to the preparation of the revolution which he hoped ardently was just around the corner. Into this struggle he poured all his energies, all his idealism, even his mysticism. The result was an odd mélange of Tolstoy, Romain Rolland and Lenin. One of his favorite ideas was that the veterans of the War must keep alive the memory of what they had seen and suffered. They must set to work immediately to sabotage the next war, which was already in preparation. Whenever possible, they must disrupt patriotic demonstrations and boo regimental flags as they passed in review. Their responsibility to oncoming generations was to throw acid on the wounds of the War as long as there was a cannon fit to fire. ${ }^{3}$ Moreover the Communists must create a mystique of internationalism, a martyrology of revolution. Without the arm of mysticism, warned Lefebvre, the forces of revolution would not conquer. Marxism alone was not enough. The orthodox Socialists of the Second International, for all their theory, had faltered when the War began, but Romain Rolland had held fast because he preserved a mystical faith in pacifism and international brotherhood. The Communists must study and follow his example. ${ }^{4}$

The Socialists gathered for their annual national congress at Strasbourg toward the end of February, I920, The advocates of Bolshevism in France intended once more to pose the question of the Third International; this time they had some hope that they would carry with

1 Raymond Lefebvre, Le Sacrifice d'Abraham, p. 260-261.

2 Quoted by Jean Bernier, Clarté, November I9, I92I.

3 La Vie Ouvrière, December 19, 1919.

4 Clarté, March 6, 1920. 
them the Party. For Lefebvre it was his first national congress and his appearance triggered an incident. The Right attempted to have him excluded from the hall because he did not have the required five years of presence in the Party. Jean Longuet defended him and invoked the special circumstances. Lefebvre was a relative newcomer and a bit excitable, it was true, admitted Longuet, but he had behind him already a long and courageous record of opposition to the War. The incident was settled and Lefebvre was permitted to remain. ${ }^{1}$ Later, hecklers accused him of having belonged to the Action Française. He denied it adamantly, adding as if in expiation of his bourgeois origins: "I had the opinions of my milieu until the age of reason. A spiritual crisis led me little by little to the revolutionary point of view." 2

At Strasbourg Lefebvre delivered a long, impassioned speech in which he spoke of the need for a war literature animated by a kind of pacifist mysticism. Turning to Renaudel, he astounded the Socialist hierarchy, long accustomed to the exaggerated politeness of parliamentary debates, by crying: "You are too healthy to understand mutilated France ..." 3 The light and robust France of your youth, he continued, to angry protests from the Right and frantic applause from the Left, has nothing in common with the twisted skeleton which has emerged from the War and which is our heritage. For this France it is a question of Revolution or Death. Lefebvre called for the promised purges and the definitive rejection of national defense. He denied that he was another Hervé or that he was preaching insurrectionalism. All he asked, concluded Lefebvre, wat that the Socialist Party prepare the Revolution, that it learn to combine the humanitarian feelings aroused by the War with the sense of organization developed by the Second International. ${ }^{4}$

The Congress of Strasbourg voted to leave the Second International but, despite the efforts of Lefebvre and his fellow members of the Committee of the Third International, it decided against immediate adherence to Moscow. Instead, the Congress voted to "reconstruct" the Second International by negotiating with the Bolsheviks and those parties which had left the Second but not yet joined the Third. By this manoeuvre the leaders of the moderate forces within the Party hoped to satisfy the evergrowing radicalism of their troops while avoiding the crushing embrace of the Bolsheviks. The Center

J Parti Socialiste, S.F.I.O., r 7e Congrès National, tenu à Strasbourg les 25, 26, 27, 28 et 29 Février 1920, p. 168-1 73.

2 Ibid., p. 256.

I Ibid., p. 256 .

4 Ibid., p. 262-263. 
still searched for a third way which would bring the Russians to Europe rather than the French to Moscow.

Lefebvre was rewarded for his new popularity within the Party by his election to the editorial board of Humanité. After the Congress he continued to work to convert the rest of the Party to his new faith in Moscow. "Constantly threatened by a relapse", recalled VaillantCouturier, "sometimes harrassed by fever, he traversed France in every direction, moving the crowds with his piercing, simple eloquence and lashing them when it was necessary." 1 Twice he was indicted by the authorities for inciting the armed services to disobedience and for having declared that Poincaré deserved the firing squad. During the great general strike of May, 1920, he expected to be arrested at every turn. Yet he continued to scurry from one meeting to another, fanning the antimilitarism of his audiences and describing to them the achievements of the Russian Revolution.

The May strike only further convinced Lefebvre that the Socialist Party must break with its old traditions and join the Third International. Briefly, he saw a revival of revolutionary spirit; for a week the French working class shook itself from its lassitude like an angry giant and acted as if it believed in its destiny. But the strike ended with the rout of the revolutionary forces and Lefebvre drew from it the conclusion that there must be a major change in the methods and organization of the revolutionary movement. ${ }^{3}$ True, one could not schedule the Revolution for such and such an hour. Mass movements had their own momentum and their own logic. But the working class organizations must be ready to utilize these movements and not be caught napping as they had been in 1919 and 1920 :

"The gigantic social movements of today are not prepared in a day nor in a month. They require a method, an ardour, a methodical and deliberate violence that can foresee, calculate, specify. They also require a faith that has never been dirtied in the mud of class collaboration." 2

And, of course, Lefebvre found this method, this ardour and this methodical violence in Bolshevism which seemed to contrast so starkly with the Jauressian traditions of French Socialism. At the same time, Lefebvre began to feel that the former leaders of the minority, Longuet, Delepine, Mistral and Pressemane, were lost to the

1 Humanité, November I, 1921.

${ }^{2}$ Humanité, June 28, 1920.

3 Antonio Gramsci came to the same conclusion after the failure of the Turin sitdown strikes in September, 1920. See Donald W. Urquidi, The Origins of the Italian Communist Party, 191 8-1924, unpublished doctoral dissertation (Columbia 1962), pp. 266-267. 
new Party that now stood on the order of the day. In September, 1919, Lefebvre had dedicated his pamphlet on "L'Internationale des Soviets" to Longuet and Delepine. Now he was upset because they and their Reconstructor friends refused to break cleanly with the Right. According to Lefebvre, the Reconstructors manoeuvred; they avoided action; they refused to accept the Zimmerwaldian concept of national defense; they shied away from the hypothesis of the seizure of power. Even worse, they flirted with the German Noskists who had murdered Karl Liebknecht and Rosa Luxembourg and did not disguise their hostility to German Communism. ". . . everything and every day", wrote Lefebvre, "compels us to fear that those with whom we have fraternally fought against the war are no longer in agreement with us on the methods or even completely on the aim of the new war..." 1 The gap between generations widened.

\section{VIII}

Soon after the general strike in May, the Party sent a delegation to Russia composed of Marcel Cachin and L.-O. Frossard. The purpose of the mission was to negotiate with the Russians concerning the entry of the French Party into the Third International and, secondarily, to enlighten the Party on the development of the Russian Revolution. Up to the summer of 1920 , it must be remembered, no French Socialist had set foot in Soviet Russia. The government had refused the necessary passports time and time again, and communications between the Bolsheviks and the French had been uncertain. Upon learning of the Party delegation which, this time, had the permission if not the approval of the government, the Committee of the Third International decided to send its own representatives. The Second World Congress had been scheduled for the end of July and the French Communists were, of course, anxious to attend and to establish contact with the center of world revolution. Since Loriot, Souvarine and Monatte were safely cached behind the walls of La Santé, where they were incarcerated for plotting against the security of the state, Lefebvre was chosen. Undoubtedly, Lefebvre agreed to make the trip with great enthusiasm since he was burning to see the Soviet paradise about which he had written and talked so much in the past months. However, in those days of cordon sanitaire the trip was hazardous without the necessary documents. Central Europe was unsettled and war raged between Russia and Poland. ${ }^{2}$

1 Bulletin Communiste, April 29, 1920.

2 Alfred Rosmer describes the difficulties of his trip to Russia for the Second World Congress in Moscou sous Lenine (Paris 1953). 
Despite the hazards of the voyage, Lefebvre reached Moscow during the summer of 1920 in time to take an active role in the deliberations of the Second World Congress. The First Congress in I9I9 had been little more than a notice of intention to create a rival international; the attendance had been meager and predominantly Russian. The Second Congress had as its task the elaboration of the statutes of the Third International and the definition of its tactic. Secondarily, it had to deal with the representatives of the German Independants and French Socialists who had come to Moscow about the conditions under which their parties might be admitted to the Communist International. Lefebvre devoted his intervention at the Congress to the condition of the French working class movement and the possibilities for the formation of a Communist Party.

Frossard and Cachin had already indicated a willingness on the part of the Reconstructors to change their name, if not their ways, and take their place among the parties of the Third International. Circumstances, both internal and external, had made further hesitation impossible. Repeated missions to the Italian and Swiss Socialists and the German Independants had yielded no results; and the attraction of the Communist International among the rank and file at home, partly through the efforts of Lefebvre and his friends, partly through the ambiguous attitude of the conservatives in the C.G.T. and the Party before the mass movements of I919 and 1920, had steadily risen.

Lefebvre warned the Congress against the dangers of admitting the Party without a thoroughgoing purge. Despite repeated promises, Renaudel and Thomas still remained within the Party. The poison of class collaboration and social-chauvinism had still to be purged. Lefebvre pointed out in his speech how thoroughly conservative the Socialist parliamentary group was, how the majority had lost the support of the masses, and how parliamentarism had been discredited. Frossard and Cachin might be sincere, he insisted, but their conversion, while spectacular, was only an individual case. Their long history of opportunism would lead the French Party into the International on the basis of a minimum program. Lefebvre urged the Congress to be demanding and pitiless; the masses, he guaranteed, would follow. ${ }^{1}$

In his free time Lefebvre travelled about Russia in the company of his two companions, Vergeat and Lepetit. Jacques Sadoul and Victor

1 Der Zweite Kongress der Kommunistischen Internationale, Protokoll der Verhandlungen vom 19. Juli in Petrograd und vom 23. Juli bis 7. August 1920 in Moskau, (Hamburg 1920), p. 270. 
Serge acted as their guides. Despite later insinuations to the contrary, it seems clear that Lefebvre was tremendously enthused with what he saw. ${ }^{1}$ Vergeat and Lepetit, however, were attentive, but reserved. Sadoul took the three pilgrims on a trip throughout the Ukraine. There, five or six times a day, three of four times a night, Lefebvre and Lepetit addressed improvised meetings of workers and peasants crowded together before them. According to Sadoul, "The admiration of Raymond Lefebvre affirmed itself without reserve. Each day he knelt down piously before the Revolution and adored it." "When he left the Ukraine", wrote Sadoul, "he was ours, absolutely Communist to the depths of his being, impatient to act and powerfully armed for action ..." 2 Serge, too, described Lefebvre's childlike delight before the huge popular demonstrations that were then and are today an integral part of the visit of an official delegation to Russia:

"While, beneath the walls of the Kremlin, on the vast sunbathed square all hung with red flags, more than two hundred thousand workers paraded, happy men, women and children acclaiming the foreign communists, Raymond Lefebvre, dressed in a loose Russian blouse, leaned his great form over the reviewing stand, as if to embrace more and more space with his glance..." 3

On September I 5 th, 1920, Lefebvre left Serge and started the journey back to France with Vergeat and Lepetit. He had been urged to remain a bit longer in Russia, but he was anxious to get back to Paris

1 The last days of Lefebvre and the circumstances in which he died have always remained obscure. Upon learning of Lefebvre's disappearance, the French press immediately hinted that he had come away disillusioned and that the Russians had no interest in seeing him, or his companions, return to France alive. (See La Liberté, Le Figaro and La Démocratie Nouvelle for December 2, 1920.) These rumours have never died and in 1928 Maurice Laporte suggested in his offhand way that he had definite evidence that Lefebvre's death had been no accident. (Les Mystères du Kremlin [Paris 1928], p. I52). These accusations, however, all rest on the supposition that Lefebvre left Soviet Russia disillusioned and there is no evidence to support this assertion. Alfred Rosmer, who was in Russia at the time, (interview, December 2, I 960) is convinced that Lefebvre returned home enthusiastic. Moreover, there are the posthumous letters of Lefebvre and the testimony of Victor Serge and Jacques Sadoul, which I cite further on. The case, of course, remains open to new evidence, but I see no reason to doubt Rosmer's contention that Lefebvre was tremendously enthused by what he saw. It goes without saying that the bourgeois and anarchist press had every reason to try to discredit the Soviet government. Laporte was a former Communist and his books are unreliable hodgepodges of memories, hearsay and invention. The Russians themselves admitted that Vergeat and Lepetit had never been fully won over to the methods of Bolshevism. It seems extremely unlikely that they would have deliberately sent them to their death. 1920 was not 1936 .

2 Bulletin Communiste, April 21, I92 I.

3 Bulletin Communiste, April 7, I921. 
in time to take part in the preparation of the Congress of Tours. Because of the blockade the three Frenchmen were forced to take the northern route and cross the White Sea in a small boat. They were never heard from again. On the $s$ th of December, Humanite published a telegram from the Soviet representative in Stockholm declaring that the three men had been given up for lost. They had left Vaida Gouba in a small sail boat. Soon after their departure a storm had broken which had raged for four days. Since the boat was bad, cabled the Russian authorities, they must have surely perished in the storm. The telegram ended simply: "We could not get a better boat." 1

Before leaving Russia, Lefebvre wrote a last letter to his friend Vaillant-Couturier in which he summed up his impressions. The tone of the letter was darkly pessimistic, the prose even more feverish than usual. Lefebvre was obsessed with the sad state of affairs that existed in the French revolutionary movement. No longer did he blame personalities, Renaudel or Longuet: "It is more serious, it is worse than that", he wrote, "it is that the Communist atmosphere itself is lacking in France. We must almost begin everything from the beginning and without dissimulating to ourselves the immensity of the task, its difficulties..." ${ }^{2} \mathrm{He}$ was more than ever convinced of the need for immediate action. Only the trip to Russia, said Lefebvre, could reveal to a French revolutionary his insufficiency and the necessity to leave behind him forever this tradition of sonorous and empty phraseology in order to prepare an era of action. He had been struck by the difference between Russian method and French indifference. "Here, in spite of the blockade, in spite of the war, everything is organized, is prepared, they are laying the foundations of a power. In France, everything rots in an atmosphere of improvidence and dishonesty, up to and including the forces of the proletariat. The hour has already struck for a Party of action." 3 The French masses, believed Lefebvre, were waiting impatiently for the creation of a true Communist Party which, liberated from any taint of bourgeois democracy, would work at the destruction of the present regime and replace it by the dictatorship of the proletariat. ${ }^{4}$ Lefebvre was hurrying home to form that Party when he died. He was thirty years old. Péguy's words still seem the fitting epitaph: "Une voix manquée et nul ne peut la suppléer..." 5

- Humanité, December 5, 1920.

2 Clarté, December 4, 1920.

3 Clarté, December 4, 1920.

4 Ibid.

5 Quoted by Daniel Halévy in his preface to Pierre Drieu la Rochelle's Mesure de la France, p. viii. 


\section{IX}

Lefebvre died, but his dream was realized. Or, perhaps, it would be better to say that his dream was in part realized, for he would have hardly been happy with the course which events took. The Communist Party was born at Tours in December, 1920, of an ill-starred union of revolutionary idealists who wished ardently to leave the past behind and battle-scarred (electoral battles, that is,) old Socialists who may have been ready to sing the Internationale in Bolshevik congresses, but who had no desire, or intention, to depart from their tried and true methods of parliamentarism and democracy. The Renaudels and the Longuets were chased away by the famous Zinoviev telegram. But Cachin and Frossard stayed on to take the leadership of the Party and even those Socialists with short memories remembered that Cachin had carried money to Mussolini in I9Is in order to persuade him to support the entry of Italy into the War and cried at the coattails of Poincaré when Strasbourg was liberated in $1918 .{ }^{1}$

The next two years would see a constant battle between the Executive of the Third International and the leadership of the French Party. For years, the French Communist Party was known as the problem child of the International. And it would not be until the thirties that a battle-tried and dependable party would be created in France. In this sense, Lefebvre's warning at the Second Congress proved true. The conversion of two men meant nothing; not even two swallows make a summer. At the Fourth World Congress in November, 1922, the French question loomed so large that Lenin, Trotsky and Bukharin all elected to sit on the commission chosen to deal with it and Zinoviev expected to lose the bulk of the Party, including Humanité. ${ }^{2}$ Lefebvre had been only too right when he observed that the Communist atmosphere was utterly lacking in France and that it would be necessary to start from the beginning. When the Communist Party was finally consolidated in France, it was the work of the embittered young men of Lefebvre's generation, the generation that had been brought to Socialism by the War.

Would Lefebvre himself have stayed on or have left in disgust

1 This may surprise those who think of Cachin as the grand old man of French Communism. During the War he was one of the most rabid of majoritaires and as late as 1922 the Left of the Communist Party insisted that he be removed from the editorship of Humanite because of his opportunism. For the story of his mission to Italy see Alfred Rosmer, Le Mouvement ouvrier pendant la guerre (Paris I936), Vol. I.

2 Just after the Fourth World Congress Lenin remarked with a twinkle in his eye to Semard and Monmousseau, the leaders of the C.G.T.U.: "Il n'y a pas de parti communiste en France. Voulez-vous en former un?" Quoted in Gérard Walter, Histoire du Parti Communiste Français (Paris 1948), p. 8. 
during the first years of the Party's tortured existence? It is very difficult, if not impossible, to say. Almost all of the men who laid the foundations for the Congress of Tours - Boris Souvarine, Alfred Rosmer, Pierre Monatte, Frossard, Loriot - had broken with, or been excluded from, the Party before 1925. ${ }^{1}$ But Vaillant-Couturier, Lefebvre's best friend, stayed on until his death.

The formation of the French Communist Party and the undermining of the moderate forces within the working class movement in the years immediately following the War was a complicated process which often bore the aspect of ineluctable historical necessity; but the evolution of Lefebvre helps to explain at least one facet of what was a many-sided development. Lefebvre had entered the War a young intellectual with a vague sense of internationalism and a belief in the destinies of the proletariat. The War had steeled his will and acted as a catalyst for his ideas. In the hell of the trenches he had become obsessed with the imminence of European decadence. He had come back from the front seriously scarred, both mentally and physically, and determined to devote his energies to the revival and purge of the Socialist Party. Still, however, he had no real ideological position apart from a feeling that his generation had been chosen to renovate France. He associated himself with the moderate forces of the minority and regarded with hostility the extremists and doctrinaires who represented the Zimmerwaldian movement in France. During the War he had placed all his hopes in Wilson and Socialist internationalism, not bothering very much to distinguish one from the other. Even as late as 1918 he identified Wilson, the League of Nations and Trotsky as forces of peace opposed to the Holy Alliance of War. And he was enough of a patriot to volunteer to go war again if the Germans occupied Amiens in the spring of I918.

In the spring of 1919, however, Lefebvre was quickly disabused of his illusions. Wilson did not make an honorable peace; or at least so it seemed to him. Within France the reaction raged; the assassin of Jaurès was acquitted and French troops were sent to suppress the Russian Revolution. Meanwhile, the Socialist Party continued to talk of reforms and voted the moderate electoral program of Leon Blum which, though recognizing the possibility of Revolution,

\footnotetext{
1 Frossard resigned from the Party at the beginning of 1923 . Boris Souvarine was excluded from the Communist International at the Fifth World Congress in 1924. Rosmer and Monatte were excluded from the Party in December of 1924 . Loriot retired from the Party in 1922 after the Third World Congress. He returned briefly in $19^{25}$ to lead the opposition to "bolshevization", but by 1926 he had broken spiritually, if not materially, with the Party.
} 
obviously included no concrete proposals for doing anything about it. Under these circumstances Lefebvre turned to Moscow. He found bis program in the regime of Soviets which seemed to have eliminated all the gloss and glitter of bourgeois democracy and to have replaced it by the reality of popular rule. Yet, Lefebvre's Bolshevism remained very personal. He borrowed from Lenin, from Tolstoy and from revolutionary syndicalism, and served up the result in that very peculiar kind of urgency and sence of destiny which was the hallmark of his generation. In short, he was a Bolshevist without being a Marxist which, odd though it may seem, was very possible in 1920.

As 1919 and 1920 passed and the French proved repeatedly that they had no intention of making a Bolshevik type revolution, or any other type for that matter, Lefebvre drifted toward ever more extreme solutions. He also became less hopeful, and though he never lost his faith in the proletariat, he suggested more than once that he thought the focus of civilization had shifted to Russia and America. Just before leaving for Russia he wrote a pamphlet entitled "La Révolution ou La Mort" in which he argued that to save the French race and to establish a lasting peace a revolution was necessary. Beyond this there was no salvation. ${ }^{1}$ In Russia, unlike so many other revolutionary pilgrims, he found the paradise which he had gone to seek. And he rushed to his death, unwilling to wait for a safer means of transportation, anxious to begin the work of building the French Communist Party, yet convinced of the difficulties which lay ahead.

Lefebvre was thus typical of a generation which had lost its faith in the future of bourgeois democracy and which sought its utopias elsewhere: in Bolshevism, in the disjointed world of Surrealism, in a chimerical nationalism or in fascism, as was to be the case later. ${ }^{2}$

\footnotetext{
1 I have not been able to locate this pamphlet, but Lefebvre referred to it often in his articles and Victor Serge summarized it in the Bulletin Communiste of April 7, I921. I assume that he wrote it in the spting of 1920.

2 Many representatives of this generation tried more than one. Jacques Doriot made the transition from militant Communism to fascism with amazing ease. Drieu la Rochelle was himself once attracted by the extreme Left. Most of the Surrealist poets either flirted with or joined the Communist Party after they discovered the incompatibility of artictic revolution and a conservative society. And it is interesting that Communism was so casily mingled with patriotism during the days of the Front populaire.
} 